\title{
Perspektif Psikoviktimologi dalam Pendampingan Dan Perlindungan Anak Korban Kekerasan Seksual
}

\author{
Reni Kusumowardhani \\ Asosiasi Psikologi Forensi (Apsifor) \\ E-mail: kusumowardhani@gmail.com
}

\section{Abstract}

Sexual violence to child is a serious crime, but on the other side, the case of sexual violence to child often difficult to proved. The Supreme Court of United States have perceived that sexual violence to child is one of the most difficult crime to detected and claimed because most of the case have not eyewitness except the victim. (Pennsylvania v. Ritchie, 480 U.S. 39, 60. 1987). In many cases, witness of eyewitness is very important matter. It become very ironic because children in one side as victim because the weakness of them, but strength of children as eyewitness is the best expectation for them to get law protection.

Kekerasan seksual terhadap anak merupakan kejahatan serius, namun di sisi lain kasus kekerasan seksual terhadap anak kerap kali sulit dibuktikan. Mahkamah Agung AS telah mengamati bahwa kekerasan seksual terhadap anak adalah salah satu kejahatan yang paling sulit untuk dideteksi dan dituntut karena kebanyakan tidak ada saksi kecuali korban (Pennsylvania v. Ritchie, 480 U.S. 39, 60. 1987). Dalam banyak kasus kesaksian saksi merupakan hal yang sangat penting. Ini menjadi sangat ironis karena anak di satu sisi sebagai korban karena kelemahan mereka, namun kekuatan anak sebagai saksi merupakan harapan terbaik mereka untuk mendapatkan perlindungan hukum.

Keywords: psikoviktimologi, perlindungan anak, kekerasan seksual

\section{Pendahuluan}

Dari aspek etimologi, viktimologi berasal dari kata victim yang berarti korban, dan logos yang berarti ilmu pengetahuan. Terminologi viktimologi dimaknai sebagai ilmu yang mempelajari tentang korban, termasuk di dalamnya mempelajari dan mengkaji penyebab terjadinya atau timbulnya korban dan akibat-akibat penimbulan korban yang dalam konteks kenyataan sosial merupakan masalah manusia. Pendekatan viktimologi ini membawa konsekuensi logis terhadap peran psikologi sebagai ilmu yang mempelajari perilaku. Adalah psikologi yang secara strategis dapat dilibatkan sebagai salah satu unsur penting dalam peranperan prevensi terhadap kemungkinan terjadinya viktimisasi, peran-peran penegakan diagnosis viktimisasi, dan peran-peran rehabilitatif pada saat korban mengalami defungsionalisasi dalam kehidupan sehari-hari akibat kejadian penimbulan korban (Kusumowardhani, 2014).

Viktimologi lahir setelah kriminologi yang diinisiasi oleh tokoh-tokoh seperti Hans von Hentig, Benjamin Mendelsohn, Stephen Schafer (O'Connell, 2013). Hal tersebut karena dalam kriminologi fokus dan orientasi lebih pada pelaku tindak pidana, kurang diperhatikan hak-hak korban dan pengembangan sistem untuk mengurangi penderitaan korban. Dalam kenyataannya korban seringkali memegang peranan yang penting dalam terjadinya kejahatan. Juga adanya sebuah paradigma baru bahwa Negara turut bersalah dalam terjadinya korban. 
Dengan adanya orientasi dan perhatian terhadap korban, maka telaah mengenai korban juga dapat memberikan manfaat dalam sistem peradilan pidana, khususnya bagi penegak hukum:

1. Bagi aparat kepolisian, viktimologi sangat membantu dalam upaya penanggulangan kejahatan. Melalui viktimologi akan mudah diketahui latar belakang yang mendorong terjadinya kejahatan, seberapa besar peranan korban pada terjadinya kejahatan, bagaimana modus operandi yang biasanya dilakukan oleh pelaku dalam menjalankan aksinya serta aspek aspek lainnya yang terkait.

2. Bagi Kejaksaan, khususnya dalam proses penuntutan perkara pidana di pengadilan, viktimologi dapat dipergunakan sebagai bahan pertimbangan dalam menentukan berat ringannya tuntutan yang akan diajukan kepada terdakwa, mengingat dalam praktiknya sering dijumpai korban kejahatan turut menjadi pemicu terjadinya kejahatan.

3. Bagi hakim tidak hanya menempatkan korban sebagai saksi dalam persidangan suatu perkara pidana, tetapi juga turut memahami kepentingan dan penderitaan korban akibat dari sebuah kejahatan atau tindak pidana, sehingga apa yang menjadi harapan dari korban terhadap pelaku sedikit banyak dapat dikonkritkan dalam putusan hakim (Mansur dan Gultom, 2006).

Mengacu pada manfaat yang ditimbun oleh berkembangnya viktimologi, dalam praktiknya peran psikologi mendapatkan ruang yang luas, khususnya psikologi forensik. Hal ini sesuai dengan amanat UU nomor 13 tahun 2006 tentang Perlindungan Saksi dan Korban. Peran-peran kunci yang dapat diberikan oleh psikologi forensik adalah:

1. Dalam tataran mikro yang langsung terkait dengan pelayanan atau pendampingan terhadap korban, yaitu advokasi kasus, maupun dalam tataran makro yang terkait dengan kebijakan, yaitu advokasi sistem (Dussich, 2013). Dalam perspektif viktimologi pada tataran fungsi mikro, psikologi forensik dibutuhkan untuk memberikan layanan psikologis terhadap korban dalam rangka memenuhi kebutuhan korban agar dapat berfungsi seperti sebelum timbulnya viktimisasi, namun tentu saja psikologi juga dibutuhkan untuk memenuhi keberfungsian dari sistem peradilan pidana sehingga peradilan pidana dapat memenuhi pemberian hak para korban.

2. Dari aspek kajian keilmuan, maupun dalam lingkup praktis. Dengan keberfungsian pada aspek mikro dan makro, maka di samping bagaimana praktik psikologi ini dapat dimanfaatkan, kajian psikologi juga sangat dibutuhkan untuk membantu proses peradilan pidana agar dapat berjalan sebagaimana mestinya sesuai dengan aturan perundangan atau hukum yang berlaku. Di sini mengandung makna preventif sebelum terjadinya sebuah tindak kriminal, pada saat sudah ada tindak pidana yang berproses mulai dari kepolisian, kejaksaan sampai ke hakim di pengadilan, dan bagaimana kemudian berlanjut pada proses rehabilitasinya. Kajian psikologi dapat membantu dalam pembuatan kebijakan, program- program pada institusi terkait sampai pada sumbangan pemikiran mengenai hukum positif yang berlaku.

Pengertian korban itu sendiri pada dasarnya secara umum dapat dikategorikan menjadi dua. Pertama, Korban dalam arti sacrifice artinya korban adalah untuk pengorbanan, yang dikaitkan dengan hal-hal yang bersifat metafisik, supranatural, misalnya korban dalam upacara keagamaan dan atau sejenisnya yang biasanya dimaksudkan untuk persembahan dewa, pengampunan, penghormatan, ungkapan terimakasih, penebusan dosa, dan sejenisnya (O’Connell, 2013).

Dalam perundang-undangan di Indonesia juga sudah dirumuskan tentang pengertian korban antara lain: 
1. PP No. 2 tahun 2002 tentang Tata Cara Perlindungan Terhadap Korban dan Saksi dalam Pelanggaran HAM Berat : "korban adalah orang perseorangan atau kelompok orang yang mengalami penderitaan sebagai akibat pelanggaran hak asasi manusia yang berat yang memerlukan perlindungan fisik, dan mental dari ancaman,gangguan, teror, dan kekerasan dari pihak manapun".

2. PP No. 3 tahun 2002 tentang Kompensasi, Restitusi, dan Rehabilitasi terhadap korban HAM berat : "korban adalah orang perseorangan atau kelompok orang yang mengalami penderitaan baik fisik, mental maupun emosional, kerugian ekonomi, atau mengalami pengabaian, pengurangan atau perampasan hak-hak dasarnya, sebagai akibat pelanggaran hak asasi manusia yang berat, termasuk korban adalah ahli warisnya".

3. UU no. 23 Tahun 2004 tentang Penghapusan Kekerasan dalam Rumah Tangga (PKDRT): "korban adalah orang yang mengalami kekerasan dan/atau ancaman kekerasan dalam lingkup rumah tangga."

4. UU No. 13 Tahun 2006 tentang Perlindungan Saksi dan Korban: "korban adalah seseorang yang mengalami penderitaan fisik, mental, dan/atau kerugian ekonomi yang diakibatkan oleh suatu tindak pidana".

5. UU No. 21 Tahun 2007 tentang Tindak Pidana Penjualan Orang (TPPO): "korban adalah seseorang yang mengalami penderitaan psikis, mental, fisik, seksual, ekonomi, dan/atau sosial yang diakibatkan oleh TPPO".

6. UU No. 24 Tahun 2007 tentang Penanggulangan Bencana: "korban bencana adalah orang atau kelompok orang yang menderita atau meninggal dunia akibat bencana"

7. UU No. 11 Tahun 2012 tentang Sistem Peradilan Anak: "korban atau Anak Korban adalah anak yang berusia kurang dari 18 tahun yang menjadi korban tindak pidana yang mengalami penderitaan fisik, mental, dan/atau kerugian ekonomi”

Dalam perkembangannya, berdasarkan jenis kejahatan yang terjadi terdapat dua kategori korban, yaitu: (1) Korban konvensional adalah korban tindak pidana yang tindak pidananya tersebut diatur dalam KUHP seperti pencurian, pembunuhan, pembunuhan dengan mutilasi, penganiayaan, perkosaan, penipuan, pemerasan, , penghinaan, pemalsuan, pencemaran nama baik, pencabulan; (2) Korban unkonvensional adalah berbagai bentuk korban baru sebagai akibat tindak pidana yang diatur dalam UU, antara lain: Korban akibat dari kejahatan komputer atau cybercrime seperti hacker yang diatur dalam UU IT; Korban kejahatan politik (korbannya lebih besar dari korban kejahatan konvensional), diatur dalam UU Politik; Korban kejahatan terhadap lingkungan seperti kerusakan ekologi, polusi, Bophal, Chernobyl, Cilincing, Buyat, yang diatur dalam UU Lingkungan; Korban kejahatan di bursa efek seperti saham palsu, internal trader; Korban kejahatan terhadap konsumen barang seperti kosmetik, obat, vcd/dvd palsu yang diatur dalam UU Perlindungan Konsumen; Korban kejahatan perdagangan senjata baik senjata konvensional maupun nuklir; Korban kejahatan perdagangan orang diatur dalam UU Tindak Pidana Perdagangan Orang dan UU Pengadilan HAM; Korban kejahatan narkotik, zat adiktif diatur dalam UU Narkotik dan Zat Adiktif; Korban kejahatan pajak dan perbankan diatur dalam UU Pajak, UU Perbankan; Korban kejahatan terorganisir seperti Triad, Yakuza, Mafia; Korban kejahatan penularan HIV/AIDS, penyakit menular diatur dalam UU Kesehatan; Korban kejahatan "merokok" diatur oleh PERDA; Korban kejahatan perdagangan bebas; Korban kejahatan terhadap penggunaan dana bantuan, JPS, BBM, bencana, keuangan negara diatur dalam UU Anti Korpsi; Korban yg bertalian dg modernisasi seperti korban lalulintas diatur dalam UU Lalulintas, UU Penerbangan, Hukum Laut; Korban media elektronik seperti TV global, internet, VCD, DVD porno yg merusak moral bangsa diatur dalam UU Pers, Multimedia, UU Anti Pornografi; Korban senjata api diatur dalam UU senjata api; Korban obat-obatan 
(thalidomit) zat pewarna, penyedap makanan diatur dalam UU Kesehatan dan UU Farmasi; Korban White Collar Crime dan Abuse of Power.Civil Service; Korban Malpraktek, Aborsi diatur dalam UU Praktek Kedokteran; Korban Teroris, Korban perang diatur dalam UU Anti Teoris, UU Humaniter; korban bencana diatur dalam UU Penanggulangan Bencana; Korban anak akibat kejahatan Pedofilia diatur dalam UU Perlindungan Anak, UU PKDRT; Korban Budaya diatur dalam UU HAM; Korban Lansia diatur dalam UU Lansia; Korban mutilasi/sunat untuk perempuan diatur dalam UU Kesehatan, , UU Perlindungan anak; Korban Eutanasia/bunuh diri diatur dalam UU kesehatan dan UU Kedokteran (Bey, 2013)

Ada beberapa jenis korban, yaitu: (1) korban ganda, (2) korban murni, (3) korban semu, (4) korban lemah mental, (5) korban lemah ekonomi, (6) korban lemah fisik, (7) korban lemah sosial, (8) korban anak (Bey, 2013). Mendelsohn membagi korban ke dalam 6 tipologi, yaitu: (1) the completely innocent victim sebagai korban "ideal", cenderung terjadi pada anak, (2) the victim with minor guilt and the victim due to his ignorance, (3) the victim as guilty as the offender and voluntary victim, (4) the victim more guilty than the offender, (5) the most guilty victim and the victim as is guilty alone. (6) the simulating victim and the image as victim (O'Connell, 2013). Sedangkan kedudukan korban dalam terjadinya suatu kejahatan dalam analisa viktimologi baik dalam tindak kriminal maupun non-kriminal menurut Wolfgang adalah: (1) Unrelated victims, yaitu korban yang tidak ada hubungannya sama sekali dengan terjadinya korban, misalnya pada kasus kecelakaan pesawat. Dalam hal ini tanggungjawab sepenuhnya terletak pada pelaku. (2) Provocative Victims, yaitu seseorang yang secara aktif mendorong dan berperan hingga ada penimbulan korban, (3) Participating Victims, yaitu seseorang yang tidak berbuat tetapi dengan sikapnya justru mendorong dirinya menjadi korban, (4) Biologically Weak Victims, yaitu mereka yang secara fisik memiliki kelemahan atau potensi untuk menjadi korban, misalnya orang tua renta, anak-anak dan orang yang tidak mampu berbuat apa-apa, (5) Socially Weak Victims, Yaitu mereka yang memiliki kedudukan sosial yang lemah yang menyebabkan mereka menjadi korban, misalnya korban perdagangan perempuan, dan sebagainya, (6) Self Victimizing Victims, yaitu mereka yang menjadi korban karena kejahatan yang dilakukannya sendiri, pengguna obat bius, judi, aborsi dan prostitusi.

Dengan memahami berbagai jenis dan tipe korban serta kedudukan korban dalam terjadinya viktimisasi, menjadi tantangan tersendiri bagi psikologi forensik untuk dapat menjalankan perannya. Peran keilmuan psikologi untuk dapat membantu penegakan diagnosa korban, memberikan sumbangan bagi penegakan keadilan bagi korban, mencegah terjadinya reviktimisasi, sampai kepada rekomendasi bagi kebijakan atau perundangan yang sudah ada. Adapun untuk peran psikolog forensik menjadi sangat dibutuhkan untuk dapat membantu korban mampu melakukan coping terhadap tindak pidana yang mengakibatkan penimbulan korban atas dirinya, mampu berfungsi dalam kehidupan kesehariannya, membantu korban untuk dapat menjalankan fungsinya dalam proses peradilan yang berjalan, menjaga segala kemungkinan terjadinya reviktimisasi atas diri korban, sampai pada memberikan rekomendasi kepada kepolisian, kejaksaan dan hakim dalam proses penegakan keadilan bagi korban.

Bahkan apabila UU Perlindungan Saksi dan Korban dicermati lebih jauh, khususnya mengenai hak-hak korban, maka peran psikologi forensik tidak berhenti sampai pada proses pengadilan oleh hakim, tetapi sampai ke proses setelah pelaku akan bebas dari masa hukumannya, psikologi forensik baik dalam keilmuannya oleh ilmuwan psikologi forensik maupun praktik psikolog forensik berperan pada bagaimana pemenuhan hak korban tersebut dapat dipenuhi oleh sistem. Ini adalah tantangan yang tidak mudah karena Psikologi di Indonesia khususnya Psikologi Forensik belum secara konsisten dilibatkan di dalam sistem, tetapi masih berada di luar sistem dan dapat menjalankan perannya hanya jika ada permintaan 
dari pelaku hukum. Masih banyak pekerjaan rumah yang harus diperjuangkan agar peran psikologi forensik yang sebetulnya sangat strategis dalam konteks viktimologi ini mendapat tempat dan kepercayaan yang lebih proporsional.

\section{Memahami Anak sebagai Korban dan Saksi Kekerasan Seksual}

Tercantum dalam UU No. 11 tahun 2012 Tentang Sistem Peradilan Anak, bahwa anak merupakan amanah dan karunia Tuhan Yang Maha Esa yang memiliki harkat dan martabat sebagai manusia seutuhnya dan berhak mendapatkan perlindungan khusus untuk menjaga harkat dan martabatnya, terutama perlindungan hukum dan sistem peradilan. Seperti telah disebutkan di atas dalam Pasal 1 UU Sistem Peradilan Anak tercantum bahwa anak yang menjadi korban Tindak Pidana atau Anak Korban adalah anak yang belum berumur 18 (delapan belas) tahun yang mengalami penderitaan fisik, mental, dan/atau kerugian ekonomi yang disebabkan oleh tindak pidana. Berdasarkan definisi korban dalam viktimologi, Anak yang menjadi korban kekerasan seksual, terlebih jika pada usia kanak-kanak yang lebih awal, merupakan the completely Innocent victim, yang menjadi korban karena memiliki kelemahan secara fisik biologis, termasuk sebagai korban non konvensional yang diatur dalam UU Perlindungan anak, UU PKDRT jika pelakunya adalah orang yang tinggal dalam satu rumah, dan UU Tindak Pidana Perdagangan Orang jika anak diperjual belikan, serta UU tentang Peradilan Anak jika pelakunya sama-sama anak. Dari jenisnya, Anak sebagai korban kekerasan seksual merupakan Korban Anak yang dianggap karena kelemahannya maka rentan menjadi korban dan kedudukannya sebagai pihak yang dirugikan.

Memahami anak sebagai korban tentu saja tidak dapat terlepas dari ciri perkembangan anak secara umum. Pada masing-masing tahapan perkembangan itu, termasuk di dalamnya adalah perkembangan emosi anak, perkembangan psikososial, perkembangan psikoseksual, dan perkembangan kognitif yang perkembangannya sangat dipengaruhi oleh interaksi antara faktor bawaan (Nature) dan belajar dari lingkungan (nurture). Tentu saja pada perkembangan yang lebih awal, anak-anak tersebut belum sampai pada perkembangan yang stabil pada setiap aspek. Apabila anak kemudian mendapatkan pengalaman buruk menjadi korban kekerasan seksual, maka peristiwa tersebut beserta konsekuensi keterlibatan anak dalam proses hukum akan mempengaruhi perkembangannya dan sebaliknya, kondisi psikologis anak dalam menjalani proses hukum juga mempengaruhi kompetensi Anak jika dibutuhkan sebagai Anak Saksi. Jangankan pada Anak, pada orang dewasa yang diminta menjadi saksi pun akan sangat mungkin merasa tidak nyaman.

Kekerasan seksual terhadap anak merupakan kejahatan serius, namun di sisi lain kasus kekerasan seksual terhadap anak kerap kali sulit dibuktikan. Mahkamah Agung AS telah mengamati bahwa kekerasan seksual terhadap anak adalah salah satu kejahatan yang paling sulit untuk dideteksi dan dituntut karena kebanyakan tidak ada saksi kecuali korban (Pennsylvania v. Ritchie, 480 U.S. 39, 60. 1987). Dalam banyak kasus kesaksian saksi merupakan hal yang sangat penting. Ini menjadi sangat ironis karena anak di satu sisi sebagai korban karena kelemahan mereka, namun kekuatan anak sebagai saksi merupakan harapan terbaik mereka untuk mendapatkan perlindungan hukum.

Salah satu simtom yang mungkin terjadi pada orang yang mengalami trauma adalah menolak membicarakan materi traumanya karena mengekspos kembali peristiwa traumatik berisiko terbangkitkannya memori negatif lengkap dengan pikiran-pikiran negatif, emosi yang meluap-luap dan sensasi fisik yang terasa tidak nyaman seolah masih atau kembali mengalami kejadian tersebut (Leeds, 2008). Oleh karena itu sangat dapat dimengerti bila pada beberapa kasus korban dengan trauma yang berat, menolak menceritakan kejadian yang dialaminya (Constanzo, 2006). Dalam hal ini Psikolog Forensik dapat membantu Anak Korban untuk mengatasi dan memulihkan traumanya, di samping juga membantu polisi, 
jaksa dan hakim dalam mendapatkan kesaksian korban sebagai Anak Saksi dengan tetap memperhatikan kondisi psikologis anak serta hak anak dan menjaga agar tidak terjadi reviktimisasi (Kusumowardhani, 2014).

Sebagai korban, anak sudah mengalami sebuah situasi yang sangat berat. Terutama pada anak-anak yang usianya lebih muda, dapat terjadi kebingungan didalam memahami dan mempersepsi sebuah relasi sosial sehingga sangat potensial mengganggu perkembangan psikososialnya. Respon orang dewasa di sekitarnya, respon teman-temannya, belum lagi jika ada media yang meliput tanpa memperhatikan psikologis anak dapat mengganggu kestabilan emosinya, sehingga banyak Anak Korban kemudian berubah perilakunya menjadi tidak seperti biasa. Pada sebagian Anak Korban mengalami ketakutan, kecemasan dan ketidakpercayaan diri.

Setiap orang bereaksi secara berbeda terhadap stres dan situasi krisis berdasarkan pada kemampuan mereka sendiri atau kebiasaan, kemampuan untuk mengatasi, serta tingkat kematangan, dan kepribadian. Bagi sebagian orang, situasi krisis dapat muncul bersamaan dengan perubahan perilaku seperti sulit tidur atau makan yang berlebihan. Bagi yang lain, krisis dapat mencakup penolakan, ketidakpercayaan, dan ketidakmampuan untuk mengatasi psikisnya atau mungkin ada yang mengalami perubahan fisiologis seperti peningkatan detak jantung, berkeringat, keluhan lambung, dan keluhan fisik lainnya (Mundy, 2013). Pada anakanak dengan tingkat kemampuan pemahaman yang masih rendah mengenai apa yang terjadi, bahkan untuk kasus kejahatan seksual yang kebanyakan dilakukan melalui bujuk rayu dan dilakukan oleh orang yang dia kenal sehari-hari, awalnya anak hanya mengalami kebingungan dan pada akhirnya merasa takut justru karena reaksi orang dewasa di sekitarnya, oleh proses hukum yang menuntut keterlibatannya, dan karena dibicarakan oleh banyak pihak. Anak yang bingung atas apa yang terjadi pada dirinya, banyak yang menyimpan sendiri berbagai pikiran dan perasaannya secara subyektif mengenai peristiwa yang dialaminya dan bereaksi dengan caranya sendiri (Kusumowardhani, 2012).

Diagnosa PTSD pada anak-anak menurut Perrin, P. Smith dan W. Yule (2000) ada beberapa kriteria:

1. Kriteria A: Mengalami Kejadian Traumatik, yaitu mengalami, menyaksikan atau terpapar pada kejadian yang menyebabkan kematian, terancam mati, cidera serius atau ancaman terhadap diri anak mau pun orang lain.

2. Kriteria B: Gejala Intrusif, seperti munculnya permainan pasca traumatik atau kegiatan bermain yang terdorong untuk dilakukan dan berulang tanpa ada penyimpangan reaksi, mencoba atau terus berkembang, pengulangan bagian-bagian trauma dalam bermain, ingatan-ingatan yang muncul kembali, adanya mimpi-mimpi buruk, episode flashbacks atau disosiasi.

3. Kriteria C: Sikap Menghindar, seperti perilaku bermain yang terbatas, meningkatnya sikap menarik diri dalam hubungan sosial, rentang emosi yang terbatas, hilangnya proses perkembangan terutama dalam hal perolehan bahasa dan perilaku kebersihan.

4. Kriteria D: Kegelisahan berlebihan seperti terjaga pada malam hari dan berteriak, sulit tidur, ketakutan terhadap gelap atau takut akan mimpi buruk, somnambulism, berkurangnya konsentrasi dan perhatian, sering terjaga, sangat mudah terkejut.

Dalam UU Sistem Peradilan Pidana Anak, dimungkinkan Anak Korban menjadi Anak Saksi guna kepentingan penyidikan, penuntutan dan pemeriksaan di sidang pengadilan yang dalam pelaksanaannya semua pihak yang terlibat wajib mempertimbangkan kepentingan terbaik bagi anak. Hak Anak Korban dan Anak Saksi dilindungi dan dijamin keamanannya baik secara fisik, psikologis dan sosial secara proporsional, yaitu memperhatikan batas 
keperluan, umur dan kondisi anak. Bahkan di dalam UU Sistem Peradilan Pidana Anak juga sudah diatur persyaratan para petugas hukum mulai dari polisi sebagai penyidik, jaksa sebagai penuntut dan hakim di pengadilan harus memahami kebutuhan perkembangan anak serta peka terhadap kondisi anak agar tidak terjadi reviktimisasi pada anak.

UU Sistem Peradilan Pidana Anak serta UU Perlindungan Anak sangat memperhatikan hak Anak baik sebagai pelaku, korban dan saksi. Permasalahannya adalah bagaimana mengintegrasikan semua pihak yang terkait agar dapat mengemban amanat UU tersebut pada saat bekerja dengan Anak Korban dan Anak Saksi. Hal ini merupakan tantangan psikologi forensik untuk dapat berperan maksimal. Anak Saksi yang juga merupakan Anak Korban mengalami beban psikologis ganda atas apa yang terjadi. Anak Saksi tidak hanya perlu didampingi agar mampu melakukan coping atas peristiwa negatif yang terjadi pada dirinya, tetapi juga perlu memberikan keterangan sebagai saksi. Kompetensi anak untuk memberikan kesaksian mensyaratkan kemampuan dasar kognitif dan kapasitas moral anak. Secara kognitif, anak harus mampu melakukan observasi dan mengingat kejadian-kejadian, harus mampu memahami perbedaan antara benar dan salah, serta memahami bahwa ia punya tugas untuk menyampaikan kebenaran baik di kepolisian saat penyidikan, di kejaksaan dan di pengadilan. Khususnya di pengadilan, pada saat kesaksian anak diambil di bawah sumpah, perlu dipertimbangkan untuk memastikan apakah anak memadai untuk hal tersebut. (Myers, 1994).

Dapat dibayangkan apabila seorang anak menjadi korban pelecehan atau kekerasan seksual yang peristiwanyapun belum dapat sepenuhnya dipahami, kemudian Anak Korban tersebut harus menjadi Anak Saksi, maka perlu dipertimbangkan level kompetensi kognitif anak tersebut dalam menjalankan perannya sebagai Anak Saksi, disamping juga bagaimana cara atau teknik yang paling ideal untuk mengungkap kesaksian anak tersebut agar pelaku hukum dalam hal ini polisi, jaksa atau hakim berhasil mendapatkan keterangan yang memadai dari Anak Saksi.

Perlindungan untuk kepentingan terbaik anak perlu diupayakan tidak hanya untuk dampak jangka pendek dan jangka panjang dari viktimisasi seksual yang sudah terjadi atas dirinya, tetapi juga pencegahan terhadap kemungkinan reviktimisasi akibat dari masih terbatasnya kognisi anak dan penalaran moralnya, terutama apabila anak masih di masa kanak-kanak awal, atau kanak-kanak akhir, bahkan juga pada masa remaja. Karakteristik perkembangan psikososial serta psikoseksual anak juga saling berinteraksi membawa implikasi bahwa perlu dibuat sebuah rancangan dalam perspektif psikoviktimologi sebagai model pendampingan Anak Korban kekerasan seksual yang sekaligus juga sebagai Anak Saksi

Peran Psikologi Forensik dengan Perspektif Psikoviktimologi: Model Mikro dan Makro

Berdasarkan perspektif psikoviktimologi, banyak peran psikologi forensik yang sangat relevan turut serta mengemban amanat UU tentang Sistem Peradilan Anak, UU tentang Perlindungan Anak, UU tentang Penghapusan Kekerasan dalam Rumah Tangga, UU tentang perdagangan manusia, UU tentang Perlindungan Saksi Korban , baik pada tataran Mikro maupun Makro dalam kasus Anak Korban Kekerasan Seksual.

\section{Advokasi Kasus: Model Mikro}

Definisi pelayanan korban dalam advokasi kasus menurut Dussich (2013) adalah rangkaian kegiatan yang dapat diberikan kepada para korban dalam menanggapi keadaan penimbulan korban atas diri mereka dengan tujuan meringankan penderitaan, memberikan bimbingan, menawarkan perlindungan, mencegah terulangnya viktimisasi oleh berbagai pihak dan memfasilitasi pemulihan.

a. Intervensi Krisis 
Pada dasarnya situasi krisis memiliki 3 elemen kunci: (1) peristiwa luar biasa, (2) persepsi dari peristiwa itu, dan (3) kemampuan korban untuk mengatasi peristiwa tersebut. Intervensi krisis adalah pemberian perawatan psikologis darurat singkat kepada para korban yang mengalami kejadian traumatis untuk mengembalikan mereka ke tingkat fungsi adaptif dan untuk mencegah reviktimisasi, serta mengurangi dampak negatif jangka pendek dan panjang. Pemberian Psychological First Aids (PFA) pada fase awal akan sangat mungkin meningkatkan kestabilan Anak Korban. Dalam hal ini, Ilmuwan Psikologi yang memiliki ketrampilan menjalankan $P F A$ dapat melaksanakan program intervensi krisis baik bersama maupun tanpa Psikolog Forensik.

\section{b. Melakukan Asesmen}

Semua intervensi, tidak peduli seberapa sederhana atau kompleks, memerlukan penilaian yang komprehensif sebelum memberikan layanan. Ini harus menjadi evaluasi psikososial yang lengkap, baik dengan tes atau wawancara korban segera setelah memungkinkan pasca viktimisasi. Tujuan utamanya adalah untuk mengetahui sejauh mana cidera psikologis dan trauma yang dialami Anak Korban. Atas dasar hasil asesmen tersebut dapat disusun dan diusulkan rencana intervensi yang bertujuan meringankan penderitaan dan memfasilitasi pemulihan agar sesuai dengan kebutuhan korban. Perlu dipilih teknik asesmen yang bersifat terapeutik di samping teknik-teknik asesmen yang umum digunakan. Ilmuwan Psikologi dapat bekerjasama dengan Psikolog Forensik (Kusumowardhani, 2014).

\section{c. Intervensi Individual: Memberikan layanan psikologis bagi Anak Korban}

Intervensi psikologis individual diarahkan untuk mengembangkan strategi coping dan meningkatkan keterampilan Anak Korban dalam menangani gejala fisik, emosional dari stres dan trauma. Berpotensi menghilangkan sebanyak mungkin penderitaan serta mempercepat kembali ke fungsi normal atau pemulihan. Pemulihan harus menjadi hasil akhir dari semua intervensi dan harus didefinisikan sebagai kriteria yang diakui serta disepakati oleh semua pendukung program. Hal dasar yang biasa dialami korban adalah: (1) terjadinya pelanggaran atas haknya sebagai manusia sekaligus hak-haknya sebagai korban; (2) mereka telah merasa kehilangan dan sakit (kadang secara fisik, kadang secara emosional, kadang keduanya); (3) dalam banyak kasus, jika ini adalah pertama kalinya terjadi pada mereka dan mereka bingung tentang apa yang harus dilakukan, di mana tempat untuk mendapatkan layanan dan bagaimana cara mengatasi situasi mereka; (4) jika mereka memiliki trauma parah dapat menyebabkan berbagai gejala: kecemasan terus menerus, respon ketakutan, kewaspadaan berlebihan, insomnia, gangguan pola makan, flashback, dan pikiran irasional. Trauma terjadi ketika jiwa tiba-tiba dihadapkan pada hal yang tidak terduga, paksaan fisik dan psikologis yang intens menyebabkan sakit atau cidera emosional dan fisik. Cidera secara emosional adalah respon normal terhadap peristiwa abnormal. Pembentukan ingatan yang berhubungan dengan emosi yang menyakitkan dapat menghasilkan fobia yang kuat. Makin langsung/intens paksaan, makin besar risiko trauma, makin banyak cidera, dan berlangsung makin lama. Mekanisme coping yang normal biasanya tidak mampu menangani serangan yang kuat ini sehingga orang sering menjadi bingung, sangat disfungsional dan sangat membutuhkan dukungan psikososial serta bantuan terapi. Terutama apabila korbannya adalah anak-anak dengan segala karakteristik perkembangannya, diperlukan sebuah pendekatan yang mempertimbangkan kepentingan terbaik untuk anak.

Perlu diupayakan pemenuhan kebutuhan psikologis Anak Korban seperti: (1) Toleransi afek yang memadai, (2) Keadaan kehidupan yang aman, (3) Kesediaan untuk menerima keadaan tak nyaman untuk sementara, (4) Kekuatan ego yang memadai, (5) Dukungan sosial atau resource lain, (6) Kerjasama yang baik sesuai pengalaman, (7) Kejelasan tentang bentuk trauma yang dialami (Eckers, 2007). Psikolog Forensik dapat merancang rencana 
intervensi individual untuk Anak Korban sesuai kebutuhan unik masing- masing Anak Korban.

\section{d. Intervensi Kelompok}

Perlu pula dipertimbangkan program-program intervensi dengan kelompok-kelompok yang efisien, misalnya dengan keluarga, bersama teman- teman yang signifikan, atau dalam kelompok bersama Anak Korban lain bila Anak Korban lebih dari satu. Pada beberapa korban akan merasa lebih nyaman dalam intervensi kelompok (Dussich, 2013). Dapat pula memanfaatkan kelompok-kelompok yang sudah pernah ada misalnya kelompok yang ada di sekolah, di Rumah Sakit atau lainnya. Keuntungan memanfaatkan sinergi dari sistem kelompok yang ada sering dapat memfasilitasi pemulihan dibanding secara individual. Untuk semua kerja kelompok perlu dipikirkan siapa yang dapat menjadi fasilitator dan koordinator yang tentunya harus orang yang terlatih. Psikolog Forensik dapat menerapkan teknik-teknik intervensi kelompok dalam bentuk terapi psikologis, dan Ilmuwan Psikologi dapat mendesain bentuk-bentuk aktivitas kelompok untuk memfasilitasi kebutuhan psikososial Anak Korban

\section{e. Memberikan layanan psikologis bagi Keluarga Anak Korban}

Keluarga, terutama orangtua Anak Korban, pada umumnya juga mengalami ketidaknyamanan psikologis, shock, krisis sampai dengan kemungkinan terjadinya trauma sekunder. Oleh karena itu keluarga terutama orangtua juga perlu mendapatkan perhatian untuk mendapatkan intervensi mulai dari asesmen, edukasi, sampai ke intervensi dan pemulihan sesuai dengan kebutuhan psikologis keluarga. Psikolog Forensik dapat melaksanakan psikoterapi sekaligus menginisiasi dampingan psikososial bersama Ilmuwan Psikologi.

\section{f. Pemulihan}

Begitu keselamatan terjamin, pemulihan korban adalah tujuan utama, yaitu kembali ke normal dan kepercayaan diri yang didefinisikan sebagai kembalinya ke tingkat yang sama atau lebih baik dari hal keberfungsiannya sebelum viktimisasi, atau secara signifikan memiliki gejala yang lebih sedikit, dan meningkatkan harga diri.

Tingkat normal diukur dengan mengikuti karakteristik: adanya kepercayaan, kembali menjalin hubungan dengan lingkungan sosialnya termasuk menjalin kedekatan atau keintiman dengan orang lain, kembali pada kemandirian dan inisiatif yang pernah dimiliki, memiliki kompetensi mengatasi gejala jika muncul, serta punya pengetahuan dan bekal untuk menangkal ancaman potensial (misalnya jika terjadi situasi potensial viktimisasi seperti yang pernah di alami). Kepercayaan Diri diukur dengan: adanya citra diri yang positif, dengan emosi yang adaptif, bisa merasakan kembali kebahagiaan/kesejahteraan psikologis.

\section{g. Penyediaan informasi}

Informasi merupakan kebutuhan utama yang sering diabaikan. Anak Korban perlu mendapatkan informasi tentang apa yang terjadi pada mereka, apa yang mungkin akan terjadi, peran apa yang kemungkinan besar harus dijalani seperti menjadi Saksi Korban dan bagaimana menghadapinya, serta bagaimana Anak Korban itu dapat mencapai pemulihan, siapa saja yang akan terlibat dalam pendampingan dan proses intervensi psikologis serta pemulihannya tersebut. Hak mendapatkan informasi ini idealnya termasuk informasi pada saat pelaku akan dibebaskan dari hukumannya, agar Anak Korban dapat menyiapkan psikologisnya untuk menghadapi kenyataan bebasnya pelaku. Hasil Ideal dari advokasi kasus adalah adanya program integratif sebagai tools yang bisa digunakan untuk membawa Anak Korban kembali pada dirinya, mendapatkan keadilan dan pemulihan lengkap, dapat menjadi Anak Saksi yang lebih kooperatif dan mampu memberikan kesaksian secara maksimal, kecil kemungkinan atau terjadinya reviktimisasi, risiko minimal pada gangguan perkembangannya kini dan masa depannya.

\section{Interseksi antara Advokasi Kasus dan Advokasi Sistem}


Advokasi Kasus memperhatikan pentingnya memahami perilaku Anak Korban, sekaligus apresiasi terhadap sistem peradilan pidana dan dampaknya bagi Anak Korban, serta kepekaan terhadap kebutuhan manusiawi dari Anak korban. Pengetahuan ini dapat sebagai dasar untuk mengurangi kemungkinan adanya kesenjangan dan tumpang tindih dalam pemberian layanan baik dari aspek hukum atau kebijakannya. Oleh karena itu perlu ada mekanisme informasi untuk kebijakan yang berorientasi pada meminimalkan penderitaan korban dan memaksimalkan pemulihan korban. Perlu diinisiasi berbagai kegiatan pendampingan Anak Korban yang menjadi Saksi untuk memberikan perlindungan sekaligus menghindari reviktimisasi yang dapat menambah penderitaan Anak Korban dan menggangu proses pemulihan. Kegiatan-kegiatan layanan dimaksud antara lain:

\section{a. Mendampingi Anak Korban yang sekaligus sebagai Anak Saksi \\ 1) Di Kepolisian}

Berurusan dengan polisi merupakan hal yang pada umumnya menimbulkan rasa takut pada anak-anak. Oleh karenanya, Ilmuwan Psikologi dan Psikolog Forensik dapat berkoordinasi dengan pihak kepolisian untuk bersama-sama menjaga kondisi psikologis Anak Korban. Sesuai dengan UU Perlindungan Anak dan UU Sistem Peradilan Anak, polisi yang bertugas perlu memiliki pengetahuan dan ketrampilan menghadapi anak-anak, dan tidak menggunakan atribut-atribut formal yang membuat Anak Saksi takut, memperhatikan tempat, waktu dengan menyesuaikan kebiasaan rutinitas harian Anak Saksi. Anak juga perlu diberi informasi mengenai hak-hak anak sebagai Saksi Korban bahwa Anak Saksi boleh menjawab tidak tahu jika memang tidak tahu dan mendorong anak agar sebaiknya menyampaikan kesaksian hanya atas apa yang betul-betul mereka alami dan saksikan. Dalam hal ini akan lebih menguntungkan jika penggalian informasi Anak Saksi melalui teknik wawancara kognitif agar didapatkan keterangan yang minim bias. Jika dibutuhkan, Psikolog Forensik dapat membantu polisi dalam menggali informasi dari Anak Saksi. Orangtua dan pihak-pihak di sekitar Anak Saksi perlu untuk menjaga kemurnian kesaksian anak dengan tidak melakukan arahan terutama arahan yang terkait dengan konten kesaksian. Anak yang masih memiliki keterbatasan dalam perkembangan kognitif dan perkembangan moralnya, perlu mendapatkan dukungan yang menenangkan. Intervensi berupa arahan terhadap konten kesaksian berisiko terjadinya bias dan menambah kebingungan anak sampai ke kemungkinan kecemasan akibat konflik antara apa yang Anak Saksi ingat dengan persepsi Anak Saksi atas harapan orang-orang di sekitarnya.

\section{2) Di Kejaksaan}

Kesaksian Anak Saksi sangat penting bagi jaksa dalam menyusun dakwaan dan tuntutan bagi pelaku. Hampir sama seperti dalam pengambilan keterangan di kepolisian, hanya saja di sini merupakan proses pengulangan yang kesekian kali. Kesejahteraan psikologis Anak Saksi perlu diperhatikan dan sebaiknya jaksa juga menggunakan prinsipprinsip seperti yang diamanatkan oleh UU Perlindungan Anak dan UU Sistem Peradilan Anak. Peran Psikolog Forensik membantu Anak Saksi mendapatkan hak-hak seperti yang diamanatkan oleh UU yang berlaku, di samping juga mendampingi proses pemulihan melalui langkah-langkah advokasi kasus.

\section{3) Di Pengadilan}

Berada di ruang pengadilan kerap menjadi hal yang sangat tidak menyenangkan bahkan bagi orang dewasa sekalipun, terlebih bagi anak-anak. Kompetensi Anak Saksi untuk bersaksi di pengadilan terutama jika harus diambil sumpah perlu diukur kembali. Dengan pertimbangan usia perkembangan Anak Saksi terutama pada perkembangan kognitif dan penalaran moralnya, serta banyaknya kejadian yang sudah dialami Anak Saksi sejak menjadi Anak Korban kemudian turut serta dalam proses hukum mulai dari tahap penyidikan di kepolisian, lalu di kejaksaan, kemudian masih harus bersaksi di pengadilan dapat 
merupakan rentetan peristiwa yang sangat melelahkan bagi Anak Saksi yang sekaligus adalah Anak Korban. Berbagai cara bersaksi dapat dipertimbangkan untuk direkomendasikan sesuai dengan kompetensi Anak Saksi untuk bersaksi. Hakim memiliki kewenangan untuk melindungi anak2 dari gangguan atau intimidasi, dan kewenangan ini berlaku dalam jalannya perkara kriminal dan umum. Hakimpun sangat disarankan menggunakan teknik wawancara kognitif untuk mengurangi kemungkinan banyaknya bias yang terjadi. dalam membantu anak menjelaskan ingatannya. Psikolog Forensik dapat melakukan asesmen terhadap kondisi psikologis Anak Saksi terkini dan memberikan rekomendasi model kesaksian yang juga dimungkinkan oleh UU kepada Hakim berdasarkan temuan hasil asesmen. Peran lain dari Psikolog Forensik adalah kemungkinan diminta sebagai saksi ahli yang menjelaskan kondisi psikologis Anak Korban dan Anak Saksi, baik sebagai saksi ahli yang melakukan pemeriksaan atas anak maupun tidak.

\section{b. Mempersiapkan Anak Korban pada saat Pelaku akan bebas}

Salah satu hak Korban adalah mendapat informasi, termasuk informasi bebasnya pelaku. Hal ini penting agar tidak terjadi retraumatisasi pada Anak Korban setelah pelaku hadir kembali di tengah kehidupannya, terutama jika pelaku adalah orang dekat atau keluarga Anak Korban. Anak perlu disiapkan agar mampu melakukan perilaku coping atas situasi yang akan dihadapinya. Psikolog Forensik juga dapat berperan untuk memediasi hubungan antara pelaku dengan keluarga Anak Korban, untuk kepentingan terbaik anak, baik saat Anak Korban sudah beranjak dewasa maupun mungkin masih dalam usia anak-anak pada saat pelaku bebas.

\section{Advokasi Sistem}

Bentuk berikutnya Advokasi Sistem, yaitu advokasi sosial sebagai "wakil" dari Anak Korban; mempromosikan Undang-Undang dan kebijakan advokasi yang berpihak pada hak Anak, yaitu:

a. Bekerjasama dengan profesi terkait dan lembaga terkait proses Perlindungan Anak, dan Perlindungan Saksi dan Korban. Hal ini penting karena dalam memberikan layanan bagi Anak Korban dan Anak Saksi tidak mungkin dilakukan sendiri secara terpisah dari proses yang berjalan dan lembaga- lembaga yang terkait. Menurut Meliala (2013) integrasi perlindungan dan pelayanan terhadap korban dalam sistem peradilan pidana di Indonesia merupakan hal penting dan menjadi kebutuhan jika ingin menjalankan prinsip- prinsip viktimologi.

b. Memberi edukasi kepada media agar tidak melakukan pemberitaan yang dapat menimbulkan dampak buruk dan viktimisasi pada Anak Korban

c. Melakukan mediasi jika dibutuhkan untuk kepentingan terbaik Anak Korban. Perspektif korban dalam sistem peradilan pidana masih relatif muda dan baru. Oleh karenanya kesadaran komprehensif tentang jenis korban dan permasalahan korban masih belum sepenuhnya terlaksana secara sinergis. Menurut Meliala (2013) masih terdapat ego sektoral dan ego profesi dalam memberikan perlindungan bagi korban.

d. Membuat Kajian-kajian dan Pengembangan Program serta Model Layanan Anak Korban,seperti :

1) Melakukan berbagai kajian dan evaluasi mengenai program layanan psikologis untuk Anak Korban dan Anak Saksi yang sudah berlangsung, melakukan inventarisasi layanan yang sudah ada, melakukan survey dari pengalaman advokasi kasus, melakukan penilaian kebutuhan, membuat pedomanpedoman atau protokol layanan, mengevaluasi dan merancang MOU yang dibutuhkan antar lembaga, membangun proses monitoring. Peran ini dapat dilakukan baik oleh Psikolog Forensik maupun ilmuwan Psikologi Forensik. 
2) Beberapa pengembangan dapat dilakukan misalnya, Program Advokasi Anak Korban dan Anak Saksi Berkebutuhan Khusus.

3) Secara aktif merancang pelatihan-pelatihan untuk meningkatkan pemahaman pelaku atau aparat hukum mengenai anak-anak serta berbagai teknik wawancara seperti wawancara kognitif untuk digunakan dalam menggali ingatan Anak Korban yang menjadi Anak Saksi.

\section{Tantangan dalam Layanan Anak Korban Kekerasan Seksual}

Meskipun psikoviktimologi memberi ruang yang sangat luas terhadap peran psikologi dan peran psikologi sudah diakomodasi dalam UU Perlindungan Saksi dan Korban, namun dalam praktiknya, peran Psikologi Forensik belum maksimal. Beberapa faktor yang menjadi latar belakang kurang maksimaln ya peran Psikologi Forensik sebagai berikut:

1. Institusi hukum dan pelaku hukum belum secara konsistem memanfaatkan jasa Ilmuwan Psikologi maupun Psikolog Forensik dalam mendampingi Anak Korban kekerasan seksual.

2. Kalaupun dilibatkan, belum ada bangunan sistem dengan konsep yang terintegrasi

3. Masih terbatasnya pengetahuan para pelaku hukum mengenai fungsi dan peran Ilmuwan Psikologi dan Psikolog Forensik. Kebanyakan pengetahuan mereka mengenai peran serta psikolog hanya di dalam pelaksanaan pemberian konseling dan psikoterapi.

4. Masih sedikitnya Psikolog di Indonesia yang meminati bidang Forensik khususnya dalam praktik pendampingan Anak Korban.

5. Kompetensi Psikolog bidang Forensik belum terstandardisasi

6. Ada kendala khususnya dalam pemeriksaan kesehatan jiwa dengan terbitnya UU Kesehatan Jiwa yang baru saja disahkan tahun 2014

7. Meskipun sudah makin banyak dilakukan, secara kualitatif dan juga kuantitatif belum banyak kajian-kajian Psikologi Forensik mengenai Sistem Peradilan Anak yang berlaku di Indonesia, baik dari aspek Undang-undangnya sendiri, evaluasi terkait pemberian dampingan psikososial dan perlindungan anak dalam proses hukum di Indonesia, kajian atas kebijakan-kebijakan yang mendukung maupun dalam evaluasi terhadap praktik Psikologi Forensik bagi anak Korban dan Anak Saksi

8. Terkait kendala terbatasnya dukungan dana operasional bagi peran serta Psikolog Forensik. Oleh karena itu penting untuk dipikirkan langkah-langkah terobosan menjalin kerjasama dengan Lembaga-lembaga terkait seperti Lembaga Perlindungan

\section{Penutup}

Saksi Korban dan meningkatkan kemungkinan layanan melalui BPJS

Dengan adanya orientasi dan perhatian terhadap korban, maka membuka peluang yang lebar bagi peran ilmu-ilmu perilaku seperti Psikologi. Namun demikian mendukung korban bukanlah hal mudah. Lembaga Perlindungan Saksi dan Korban juga masih mencari bentuk terbaik perihal perlindungan dan pelayanan bagi korban. Asosiasi Psikologi Forensik bersama organisasi induknya Himpunan Psikologi Indonesia, aktif mengikuti proses koordinasi guna mendapatkan format layanan yang paling memadai. Beberapa hal yang masih dan harus terus diupayakan adalah:

1. Mendorong dan mendukung LPSK sebagai institusi Negara yang khusus dibentuk untuk memberikan perlindungan terhadap saksi dan korban termasuk di dalamnya Anak Saksi dan Anak Korban dalam perspektif psikoviktimologi.

2. Mendorong pengembangan keilmuan dan praktik Psikologi Forensik di Indonesia, termasuk program pendidikan berkesinambungan untuk meningkatkan kompetensi Ilmuwan Psikologi dan Psikolog Forensik guna mendukung ketersediaan tenaga professional psikologi forensik. 
3. Mengupayakan agar Psikologi Forensik dapat terlibat aktif secara konsisten dalam sistem peradilan pidana, khususnya dalam hal ini adalah perlindungan Anak Korban dan Saksi kasus Kekerasan seksual, bersinergi dengan bidang-bidang keilmuan dan profesi lain yang terkait.

Bagaimanapun juga, Psikologi memiliki tanggungjawab moral untuk berperan dalam memberikan perlindungan bagi anak-anak, termasuk Anak Korban kekerasan seksual demi menjalankan amanat Undang-undang menjamin kepentingan terbaik untuk anak.

\section{Daftar Pustaka}

Atkinson, R.L., Atkinson, R.C., dan Hilgard, E.R. (1999). Pengantar Psikologi. Edisi ke delapan Jilid 2. Jakarta: Penerbit Erlangga.

Berk, Laura.E. (1997). Child Development Fourth Edition. Masschusetts: Allyn and Bacon. Bey, F. The Development of Victimology in Indonesia. Materi Training of Trainers on

Victimology and Victim Assistance. Lembaga Perlindungan Saksi dan Korban (LPSK). 18 - 28 Maret 2013.

Constanzo, M. (2006). Aplikasi Psikologi dalam Sistem Hukum. (H.P. Soetjipto dan S.M. Soetjipto, Alih Bahasa). Yogyakarta : Pustaka Pelajar

Dikdik M. Arief Mansur, Elisatris Gultom (2006). Urgensi Perlindungan Korban Kejahatan, antara norma dan realita, Bandung.

Dussich, J.P.J. (Tokiwa International Victimology Institute). Concepts dan Forms of Victim Services - Micro. Materi Training of Trainers on Victimology and Victim Assistance. Lembaga Perlindungan Saksi dan Korban (LPSK). 18 - 28 Maret 2013. 
Dussich, J.P.J.(Tokiwa International Victimology Institute). Concepts dan Forms of Victim Services - Macro. Materi Training of Trainers on Victimology and Victim Assistance. Lembaga Perlindungan Saksi dan Korban (LPSK). 18 - 28 Maret 2013.

Eckers,D. (2008). Emotional Stabilization and Regulation. Handout of Psychotraumatology and Eye Movement Desensitization Reprocessing

http://www.citizensinformation.ie/en/justice/witnesses/witnesses_under_17_yeaError!Hyperl ink reference not valid.

Pelatihan. RSUD Cilacap.

Kusumowardhani, R. (2014). Asesmen Terapeutik Anak Korban Kekerasan Seksual. Makalah Pelatihan. Klinik Terpadu UI. Jakarta.

Kusumowardhani, R.Viktimologi dan Model Layanan Psikologis dalam Pendampingan Saksi dan Korban. Workshop Temu Ilmiah Nasional V Apsifor Himpsi. Bali. 1 Maret 2014

Leeds, A.M. (2009). A Guide to The Standard EMDR Protocols for Clinicians, Supervisors, and Consultants. New York: Springer Publishing Company.

Meliala, A. Integrasi Perlindungan dan Pelayanan Terhadap Korban Dalam Sistem Peradilan Pidana Indonesia. Materi Training of Trainers on Victimology and Victim Assistance. Lembaga Perlindungan Saksi dan Korban (LPSK). 18 - 28 Maret 2013.

Mundy, K.G., (Tokiwa International Victimology Institute). Crisis Intervention. Materi Training of Trainers on Victimology and Victim Assistance. Lembaga Perlindungan Saksi dan Korban (LPSK). 18 - 28 Maret 2013.

Mundy, K.G.,(Tokiwa International Victimology Institute). Psychological Intervention.Materi Training of Trainers on Victimology and Victim Assistance. Lembaga Perlindungan Saksi dan Korban (LPSK). 18 - 28 Maret 2013.

Myers,JEB., (1994). Adjudication of Child Sexual Abuse Cases. Article on The Future of Children. www. Princeton.edu.

O'Connell,M. (Commissioner for Victims' Rights. Government of South Australia). History of Victimology. Materi Training of Trainers on Victimology and Victim Assistance. Lembaga Perlindungan Saksi dan Korban (LPSK). 18 - 28 Maret 2013.

Papalia, D.E., Olds, S.W., dan Feldman, R.D. 2001. Human Development eighth edition. New York: McGraw - Hill.

PP No. 2 tahun 2002 tentang Tata Cara Perlindungan Terhadap Korban dan Saksi dalam Pelanggaran HAM Berat

PP No. 3 tahun 2002 tentang Kompensasi, Restitusi, dan Rehabilitasi terhadap korban HAM berat

UU no. 23 Tahun 2004 tentang Penghapusan Kekerasan dalam Rumah Tangga

UU No. 13 Tahun 2006 tentang Perlindungan Saksi dan Korban

UU No. 21 Tahun 2007 tentang Tindak Pidana Penjualan Orang

UU NO 24 Tahun 2007 tentang Penanggulangan Bencana

UU Nomor 11 Tahun 2012 tentang Sistem Peradilan Anak 